\title{
Optimization of a Microplate-Based Assay to Assess Esterase Activity in the Alga Pseudokirchneriella subcapitata
}

\author{
Manuela D. Machado • Eduardo V. Soares
}

Received: 11 May 2012 / Accepted: 6 November 2012 /Published online: 24 November 2012

(C) Springer Science+Business Media Dordrecht 2012

\begin{abstract}
The present work describes the optimization of a short-term assay, based on the inhibition of the esterase activity of the alga Pseudokirchneriella subcapitata, in a microplate format. The optimization of the staining procedure showed that the incubation of the algal cells with $20 \mu \mathrm{molL}^{-1}$ fluorescein diacetate (FDA) for $40 \mathrm{~min}$ allowed discrimination between metabolic active and inactive cells. The shortterm assay was tested using $\mathrm{Cu}$ as toxicant. For this purpose, algal cells, in the exponential or stationary phase of growth, were exposed to the heavy metal in growing conditions. After 3 or $6 \mathrm{~h}$, cells were subsequently stained with FDA, using the optimized procedure. For $\mathrm{Cu}$, the 3- and 6-h $\mathrm{EC}_{50}$ values, based on the inhibition of the esterase activity of algal cells in the exponential phase of growth, were 209 and $130 \mu \mathrm{g}$ $\mathrm{L}^{-1}$, respectively. P. subcapitata cells, in the stationary phase of growth, displayed higher effective concentration values than those observed in the exponential
\end{abstract}

M. D. Machado $\cdot$ E. V. Soares $(\square)$

Bioengineering Laboratory-CIETI, Chemical Engineering Department, ISEP-School of Engineering of the Polytechnic Institute of Porto,

Rua Dr. António Bernardino de Almeida, 431,

4200-072 Porto, Portugal

e-mail: evs@isep.ipp.pt

M. D. Machado $\cdot$ E. V. Soares

IBB-Institute for Biotechnology and Bioengineering, Centre for Biological Engineering, Universidade do Minho,

Campus de Gualtar,

4710-057 Braga, Portugal phase. The 3- and 6-h $\mathrm{EC}_{50}$ values for $\mathrm{Cu}$, for cells in the stationary phase, were 443 and $268 \mu \mathrm{gL}^{-1}$, respectively. This short-term microplate assay showed to be a rapid endpoint for testing toxicity using the alga $P$. subcapitata. The small volume required, the simplicity of the assay (no washing steps), and the automatic reading of the fluorescence make the assay particularly well suited for the evaluation of the toxicity of a high number of environmental samples.

Keywords Bioassay Fluorescein diacetate (FDA) · Growth phase $\cdot$ Microplate assay $\cdot$ Metabolic activity $\cdot$ Selenastrum capricornutum

\section{Introduction}

The worldwide industrialization that occurred in the last century has increased the ecological problems and triggered the need of developing acute and chronic laboratory toxicity tests for assessing the impact caused by many thousands of chemicals released in the environment. The present chronic (with microorganisms) and acute (using invertebrates or fishes) benchmark tests proposed by international regulatory agencies, such as the Organisation for Economic Cooperation and Development (OECD) and the United States Environmental Protection Agency (US EPA), give slow responses (within days) (OECD 1984, 1992; US EPA 2002a, b). The long time (days) required for these chronic and acute toxicity tests can alter the 
original toxicity of the sample in test due to (1) the release of metabolites by the microorganism (under the toxic effect), which can complex the metals under evaluation (Soares et al. 2002, 2003), (2) the biochemical and photochemical degradation occurrence during the time of testing, and (3) the loss of contaminants due to the adsorption to test containers (Franklin et al. 2005). Therefore, the development of new tools for a fast (within hours) assessment of the hazard and ecological risk caused by the release of contaminants in aquatic systems becomes important.

Esterases have been recognized as a potential useful biomarker and alternative endpoint for the detection of early responses in a variety of microorganisms (Dorsey et al. 1989; Blaise et al. 2000; Bitton 2005; Peperzak and Brussaard 2011) to different toxicants. Esterases were used to evaluate the toxicity of heavy metals, such as $\mathrm{Cd}, \mathrm{Cu}, \mathrm{Hg}, \mathrm{Pb}$, and $\mathrm{Zn}$ (Arsenault et al. 1993; Snell et al. 1996; Franklin et al. 2001), organic compounds such as phenol and naphthol (Snell et al. 1996), brominated flame retardant (Debenest et al. 2011), pesticides and insecticides (Gilbert et al. 1992; Snell et al. 1996), and in natural samples like surface seawater (Gilbert et al. 1992), freshwater sediments (Blaise and Menard 1998), interstitial water (Cote et al. 1998), and acid mine drainage (Regel et al. 2002).

Esterase activity has been measured using the nonfluorescent fluorescein diacetate (FDA) substrate, which is hydrolyzed by the action of intracellular nonspecific esterases, such as lipase and acylase (Jochem 2000). As the toxic effect increases, the enzyme activity is reduced in a dose-dependent manner. Therefore, $1 \mathrm{~h}$ (Franklin et al. 2001; Regel et al. 2002), $3 \mathrm{~h}$ (Franklin et al. 2005), $4 \mathrm{~h}$ (Blaise et al. 2000), $24 \mathrm{~h}$ (Blaise and Menard 1998; Regel et al. 2002; Franklin et al. 2005; Prado et al. 2009; Debenest et al. 2011), $27 \mathrm{~h}$ (Arsenault et al. 1993), or $28 \mathrm{~h}$ assay (Gala and Giesy 1994), based on the evaluation of the toxic effect on the esterase activity of algal cells, measured by flow cytometry, was reported.

Microplate readers are much cheaper equipment than flow cytometers. Additionally, the automation confers the possibility of the test to be used for the screening of large numbers of samples. Gilbert et al. (1992) evaluated the loss of intracellular esterase activity, using a microplate fluorometer, in marine microalgae exposed to heavy metals and organic compounds (weed killers and insecticides). As far as we know, only one work was dedicated to rapid toxicity assessment by evaluating the esterase activity in $P$. subcapitata using a microplate fluorometer. In this work, the concentration of the toxicant that inhibited a given percentage of esterase activity (effect concentration [EC] value) was not determined; the toxicity was evaluated based on the determination of the no observed effect concentration (NOEC) and the lowest observed effect concentration (LOEC) (Snell et al. 1996).

The evaluation of the toxicity of pollutants is, usually, carried out with cells in the exponential phase of growth. However, the effect of algal cells growth phase on EC values has not been evaluated.

In the present work, a microplate assay based on the inhibition of the esterase activity in whole cells of the alga $P$. subcapitata was optimized. The applicability of the short-term assay ( 3 or $6 \mathrm{~h}$ ) was tested using $\mathrm{Cu}$ as toxicant. The EC values were determined. The influence of the alga growth phase on the susceptibility to toxicants was also investigated and discussed.

\section{Material and Methods}

\subsection{Strain, Media, and Culture Conditions}

In this work, the freshwater green alga Pseudokirchneriella subcapitata (strain 278/4) was used. The original strain was obtained from the Culture Collection of Algae and Protozoa, Oban, UK.

The alga was maintained in OECD algal test medium (OECD 1984) with $20 \mathrm{gL}^{-1}$ agar (Merck) in the dark at $4{ }^{\circ} \mathrm{C}$. Medium stock solutions were prepared, sterilized (by autoclaving or by membrane filtration, pore size of $0.45 \mu \mathrm{m}$ ), and stored (in the dark at $4{ }^{\circ} \mathrm{C}$ ) according to the OECD guidelines (OECD 1984). Algal cells were also stored in the dark at $4{ }^{\circ} \mathrm{C}$ as stock cultures. Algal stock cultures were obtained from cultures in the exponential phase of growth (2 days) which were centrifuged $(2,500 \times g, 5 \mathrm{~min})$, washed, and resuspended in fresh medium.

The starter cultures were prepared weekly by inoculating a loop of algal cells (from agar slant) in $20 \mathrm{ml}$ OECD medium in $100 \mathrm{ml}$ Erlenmeyer flasks. The cells were incubated for 2 days, at $25{ }^{\circ} \mathrm{C}$, on an orbital shaker at $100 \mathrm{rpm}$, under continuous "cool white" fluorescent light (fluorescent lamps with a color temperature of 4,300 K), with an intensity of 4,000 lx at the surface of the flask, verified using an illumination 
meter (HI 97500, Hanna Instruments). The precultures were prepared by inoculating $40 \mathrm{ml}$ OECD medium in $100 \mathrm{ml}$ Erlenmeyer flasks with an initial cell concentration of $\sim 5 \times 10^{4}$ cells $\mathrm{ml}^{-1}$ from the starter cultures. The cells were incubated for 2 days under the conditions described previously for the starter cultures. The cultures were prepared by inoculating 100 or $400 \mathrm{ml}$ of OECD medium in $250 \mathrm{ml}$ or $1 \mathrm{~L}$ Erlenmeyer flasks, respectively, with an initial cell concentration of $\sim 5 \times$ $10^{4}$ cells ml ${ }^{-1}$ from the preculture. Cells were incubated under the conditions described previously for the starter cultures. The purity of the cultures was verified by microscopic examination of a subsample; additionally, $1.0 \mathrm{ml}$ of the algal culture was removed, plated on nutrient agar, and incubated at $25^{\circ} \mathrm{C}$ for 7 days.

\subsection{Evaluation of Cell Concentration}

The algal cell concentration was measured in an automated cell counter (TC10, Bio-Rad). Additionally, the algal concentration was evaluated, indirectly, by measuring spectrophotometrically the absorbance at $750 \mathrm{~nm}$ (US EPA 2002b); in the latter, a calibration curve (number of cells versus absorbance) was first constructed.

\subsection{Optimization of Cell Staining with FDA}

Algal cells in the exponential phase of growth (2 days) were harvested by centrifugation $(2,500 \times g, 5 \mathrm{~min})$ and suspended in fresh culture medium. Cell suspensions were combined with the same volume of FDA (SigmaAldrich) in a 96-well flat microplate (Orange Scientific) in a total volume of $200 \mu \mathrm{l}$ per well. The concentration range of cells tested was $0.5-10 \times 10^{5}$ cells $\mathrm{ml}^{-1}$ (final concentration). The concentration range of FDA used was 5-40 $\mathrm{molL}^{-1}$ (final concentration). The stock solution of FDA $\left(1.2 \mathrm{mmolL}^{-1}\right)$ was prepared in dimethyl sulfoxide (DMSO) and stored at $-20{ }^{\circ} \mathrm{C}$; the working solutions $\left(10-80 \mu \mathrm{molL}^{-1}\right)$ were prepared before use by diluting the stock solution in culture media. In the assay, the final concentration of DMSO was $\leq 3.3 \%(v / v)$. Cells were incubated with FDA in the dark at $25^{\circ} \mathrm{C}$ up to $60 \mathrm{~min}$.

As negative control, algal cells were metabolically inactivated by thermal treatment. Therefore, algal cells in OECD culture medium were placed in a glass tube and heat-treated $\left(65^{\circ} \mathrm{C}\right.$ for $\left.1 \mathrm{~h}\right)$ in a water bath. Then, cells were cooled to room temperature and stained in the same conditions of live cells.
Fluorescence intensity (in relative fluorescent units) was measured in a PerkinElmer (Victor3) microplate reader at a fluorescence excitation wavelength of 485/ $14 \mathrm{~nm}$ and an emission wavelength of 535/25 nm. Fluorescence was corrected by subtracting cell, culture medium, and dye autofluorescence and was normalized, when appropriate, considering cell concentration.

\subsection{Evaluation of Copper Toxicity}

Algal cells were exposed to copper in a similar way to the algal microplate growth toxicity test described by Blaise and Vasseur (2005). Briefly, algal cells were harvested by centrifugation $(2,500 \times g, 5 \mathrm{~min})$ and suspended at $5.5 \times 10^{6}$ cells ml $^{-1}$ in concentrated culture medium. Ten concentrations of copper (in a range of 5.6 to $1,000 \mu \mathrm{gL}^{-1}$ ) were prepared by geometrical dilution of the toxicant in deionized water. The assays were carried out in sterile 96-well microplates. The test solutions were dispensed in the microplate in a predetermined pattern as described by Blaise and Vasseur (2005). Each well received $200 \mu \mathrm{l}$ of the appropriate dilution of the metal (five replicates) or deionized water as a positive control (ten replicates) and $20 \mu \mathrm{l}$ of a cell suspension in culture medium 11 times concentrated (final cell concentration, $5 \times 10^{5}$ cells $\mathrm{ml}^{-1}$ ). The microplates were covered, sealed with Parafilm, and incubated at $25{ }^{\circ} \mathrm{C}$ under continuous "cool white" fluorescent light (as described above).

After 3 or $6 \mathrm{~h}$ of contact with metal, $10 \mu \mathrm{l}$ of a solution prepared by the mixture of equal volumes of FDA (920 $\mathrm{molL}^{-1}$ in acetone) and 3 - $(N$-morpholino)propanesulfonic acid (MOPS) buffer (SigmaAldrich) (460 $\mathrm{mmolL}^{-1}, \mathrm{pH} 7.0$, in OECD medium) was added to each well; final concentrations in the assay were $20 \mathrm{mmolL}^{-1} \mathrm{FDA}$ and $10 \mathrm{mmolL}^{-1}$ MOPS. The final concentration of acetone was $2.1 \%$ $(v / v)$. The microplates were incubated in the dark at $25^{\circ} \mathrm{C}$. After $40 \mathrm{~min}$ of incubation, fluorescence intensity was measured, as described previously. Fluorescence was corrected by subtracting cell, culture medium, dye, and metal autofluorescence.

The percentage of fluorescence inhibition $(\% \mathrm{FI})$ was calculated using the following equation:

$$
\% F I=100-\left[\left(F_{a} / F_{\max }\right) \times 100\right]
$$

where $F_{\mathrm{a}}$ is the fluorescence of algal cells in the assay (metal-treated cells) and $F_{\max }$ is the mean fluorescence 
of the samples where all the cells are metabolically active (live cells-positive control).

\subsection{Fluorescence Microscopy}

Cells were also examined by epifluorescence microscopy. Algal cells $\left(1 \times 10^{6}\right.$ cells $\left.\mathrm{ml}^{-1}\right)$ were mixed with $20 \mu \mathrm{molL}^{-1}$ FDA (final concentration) and incubated in the dark for $40 \mathrm{~min}$ at $25^{\circ} \mathrm{C}$. Then, algal cells were observed using a Leica DLMB epifluorescence microscope, equipped with HBO-100 mercury lamp and filter set GFP or I3 from Leica. Filter set GFP: excitation filter (band-pass filter [BP]), BP 470/40; dichromatic mirror, 500; and suppression filter, BP 525/50. Filter set I3: excitation filter, BP 450-490; dichromatic mirror, 510; and suppression filter (long-pass filter [LP]), LP 515. Images were acquired with a Leica DC 300F camera and processed using Leica IM 50Image manager software.

\subsection{Reproducibility of the Results and Statistical Analysis}

All experiments were repeated four times. Fluorescence data were expressed as the mean \pm standard deviation (SD) of quintuplicate measurements; SD values were presented with $95 \%$ confidence limits.

Copper toxicity was expressed as $\mathrm{EC}_{10}$ and $\mathrm{EC}_{50}$ values, which represent the concentration of the toxicant that caused the inhibition of 10 and $50 \%$ of fluorescein fluorescence (esterase activity), respectively, compared to the positive control (cells not exposed to the toxicant). EC values were calculated considering that the concentration-response relationship can be described by the probit function; EC values were obtained using weighted linear regression analysis on probit-transformed data (TOXCALC version 5.0.32, Tidepool Scientific Software).

\section{Results}

\subsection{Staining with FDA: Cell Loading and Fluorescence Development}

FDA is hydrophobic, colorless, and nonfluorescent. It diffuse freely into undamaged cells, being hydrolyzed into a more polar fluorescent product (fluorescein) and two acetate molecules; fluorescein has a maximum fluorescence at $525 \mathrm{~nm}$ (Haugland 2005). As a consequence, "healthy" cells displayed green fluorescence (Fig. 1a), while heat-treated metabolically inactive cells (dead cells) remained unstained (Fig. 1d). When observed with an LP suppression filter set (I3), it was possible to observe, simultaneously, the green fluorescence (due to the esterase activity) and the red autofluorescence (due to the chlorophyll $a$ ) in live cells (Fig. 1b); on the contrary, both types of fluorescence were absent in heat-treated (dead) cells (Fig. 1e).

The decrease of fluorescence can be used as an indicator of the loss of enzymatic activity. It was our objective to evaluate the esterase activity of $P$. subcapitata algal cells using a 96-well microplate reader. Thus, in order to optimize the staining conditions, different FDA concentrations $(5,10,20$, and $\left.40 \mu \mathrm{molL}^{-1}\right)$ and staining times $(5,10,20,30,40$, 50 , and $60 \mathrm{~min}$ ) were considered.

The fluorescence of metabolically active cells increased with the initial FDA concentration up to $20 \mathrm{mmolL}^{-1}$ (Fig. 2). The maximum fluorescent signal was obtained for $20 \mu \mathrm{molL}^{-1}$ FDA. The exposition of algal cells to $40 \mu \mathrm{molL}^{-1}$ FDA did not originate a higher fluorescence (Fig. 2).

For an FDA concentration of $20 \mu \mathrm{molL}^{-1}, P$. subcapitata algal cells hydrolyzed FDA in a linear fashion up to $60 \mathrm{~min}$ (Fig. 2, inset). Similar results were obtained with other FDA concentrations tested (data not shown). An incubation time of $40 \mathrm{~min}$ was chosen since a strong fluorescent signal was observed (Fig. 2).

The green fluorescence due to FDA hydrolyses increased linearly with the live cell concentration (Fig. 3). With the aim to obtain a good discrimination between metabolically active and inactive cells with a lower cell density, a total cell concentration of $5 \times 10^{5}$ cells $\mathrm{ml}^{-1}$ was selected for subsequent assays (evaluation of the susceptibility of $P$. subcapitata algal cells to $\mathrm{Cu}$ ). Then, the following staining conditions were selected: $20 \mu \mathrm{molL}^{-1}$ FDA for $40 \mathrm{~min}$ with $5 \times 10^{5}$ cells $\mathrm{ml}^{-1}$.

\subsection{Growth Phase and Cell Susceptibility to Toxicant}

Under the growth conditions used $\left(25^{\circ} \mathrm{C}\right.$ and continuous light), $P$. subcapitata algal cells proliferated in OECD medium with a specific growth rate $(\mu)$ of $0.063 \mathrm{~h}^{-1}$, which corresponded to a doubling (generation) time of $11 \mathrm{~h}$. Using an initial cell density of $5 \times 10^{4}$ cells $\mathrm{ml}^{-1}$ and after 2,3 , and 4 days of 

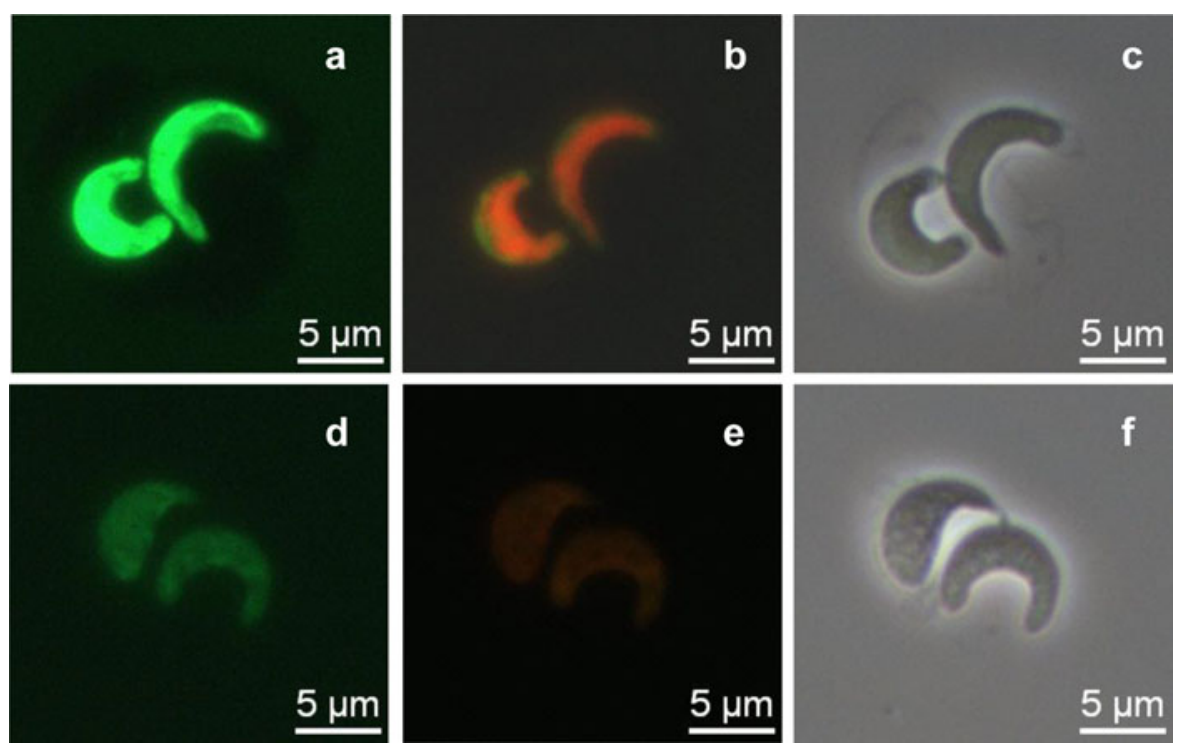

Fig. 1 Visualisation of esterase activity on the alga $P$. subcapitata. Cells were incubated with $20 \mu \mathrm{molL}^{-1} \mathrm{FDA}$ for $40 \mathrm{~min}$ at $25{ }^{\circ} \mathrm{C}$. Metabolically active (live) cells displayed bright green fluorescence (a), which was absent in heat-treated (dead) cells (d). Fluorescent micrographs of the cells observed with filter set GFP (a, d); phase contrast micrographs of the same cells $(\mathbf{c}, \mathbf{f})$.

growth, cells were in the exponential phase, at the end of the exponential phase, or in the stationary phase of growth, respectively (Fig. 4). In order to test the influence of the growth phase on the susceptibility of $P$.

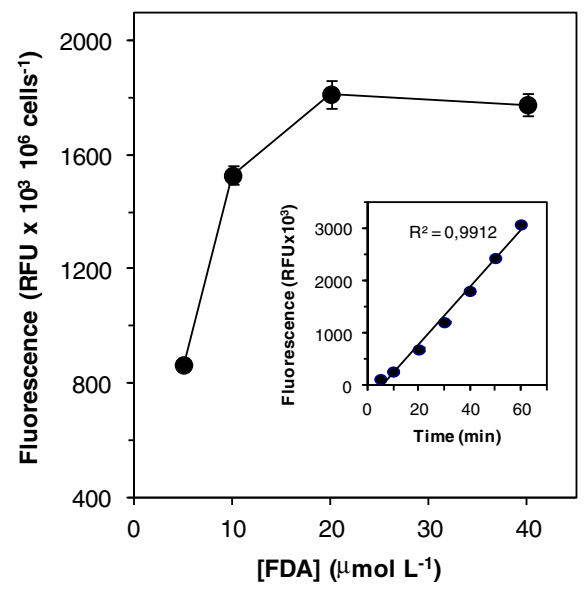

Fig. 2 Fluorescence exhibited by $P$. subcapitata algal cells when incubated with increasing concentrations of FDA. Live algal cells in a final concentration of $1 \times 10^{6}$ cells $\mathrm{ml}^{-1}$ were incubated with different FDA concentrations for $40 \mathrm{~min}$ at $25{ }^{\circ} \mathrm{C}$. Inset time course of fluorescence exhibited by live algal cells $\left(1 \times 10^{6}\right.$ cells ml $\left.{ }^{-1}\right)$ incubated with $20 \mu \mathrm{molL}^{-1} \mathrm{FDA}$ at $25^{\circ}$ C. This is a typical example of an experiment performed four times. Each point represents the mean of five fluorescence readings; SDs are presented with $95 \%$ confidence limits
Fluorescence images $(\mathbf{b}, \mathbf{e})$ were obtained with an LP suppression filter set (I3), which allowed the simultaneous observation of the green fluorescence (due to the esterase activity) and the red autofluorescence (due to the chlorophyll $a$ ) in live cells (b); both types of fluorescence were absent in heat-treated (dead) cells (e)

subcapitata cells to $\mathrm{Cu}, 2$ and 4 days as growth time were selected, which corresponded to exponential and stationary phases of growth, respectively.

Cells of $P$. subcapitata, in the exponential or stationary phase of growth, were exposed to $\mathrm{Cu}$ (in a

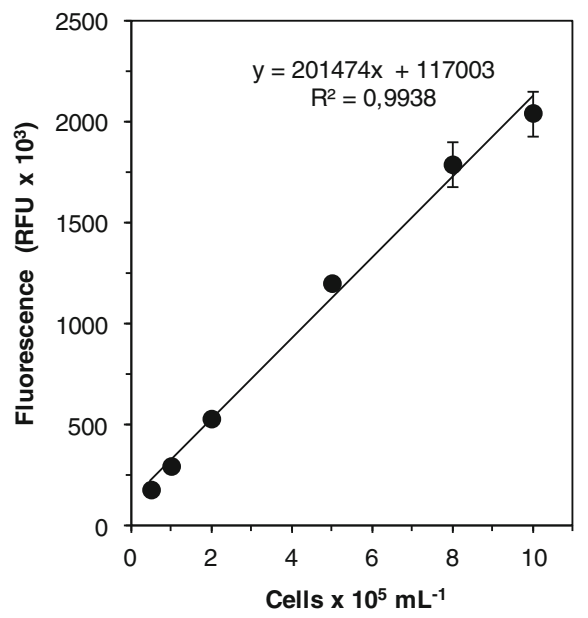

Fig. 3 Esterase activity (fluorescence response) of live cells of P. subcapitata. Cells were incubated with $20 \mu \mathrm{molL}^{-1}$ FDA for $40 \mathrm{~min}$ at $25^{\circ} \mathrm{C}$. This is a typical example of an experiment performed four times. Each point represents the mean of five fluorescence readings; SDs are presented with $95 \%$ confidence limits 


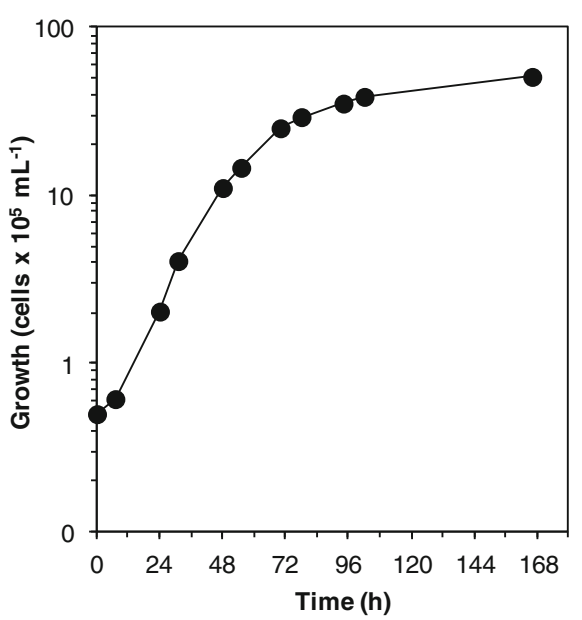

Fig. 4 Growth of the alga $P$. subcapitata. Cells were inoculated at $5 \times 10^{4}$ cells ml $\mathrm{ml}^{-1}$ in OECD medium and incubated at $25^{\circ} \mathrm{C}$ on an orbital shaker at $100 \mathrm{rpm}$ under continuous "cool white" fluorescent light. This experiment was performed in duplicate. Each point represents the mean of four determinations. No error bars are shown because they are within the points

concentration range from 5.6 to $1,000 \mu \mathrm{gL}^{-1}$ ) for 3 or $6 \mathrm{~h}$ at $25{ }^{\circ} \mathrm{C}$ under continuous light. After exposure to the metal, cells were incubated with FDA (under the optimal staining conditions defined previously) in order to assess the sensitivity of algal cells esterase activity as a short-term bioassay endpoint. The inhibition of esterase activity was evaluated by the $\% \mathrm{FI}$, which was calculated as the ratio between the fluorescence in the assay (for a given metal concentration) and the mean fluorescence of the population where all cells are metabolically active (live cells-positive control). Subsequently, dose-response curves were obtained by plotting the \%FI against the range of concentrations of the toxicants (Fig. 5). In algal cells in the exponential or stationary phase of growth, $\mathrm{EC}_{10}$ and $\mathrm{EC}_{50}$ values were determined (Table 1).

Esterase activity decreased as the metal concentration increased. Maximum esterase inhibition (84\%) was observed for cells in the exponential phase of growth after exposure to $1,000 \mu \mathrm{gL}^{-1} \mathrm{Cu}^{2+}$ for $6 \mathrm{~h}$ (Fig. 5b).

The increase of the contact time from 3 to $6 \mathrm{~h}$ led to a decrease of the amount of $\mathrm{Cu}$ necessary to provoke the same inhibitory effect (Fig. 5; Table 1). In other words, the EC values for $3 \mathrm{~h}$ are 1.4-3.4 times higher than the corresponding values for $6 \mathrm{~h}$ (Table 1).

Cells in the exponential phase of growth were more sensitive to copper than cells in the stationary phase
(Fig. 5). In the exponential phase of growth, EC values for $P$. subcapitata algal cells were two times more sensitive to the action of copper (except for the 6$\mathrm{h} \mathrm{EC} \mathrm{E}_{10}$ values, which were similar) than the same cells in the stationary phase (Table 1).

\section{Discussion}

FDA has been used as a technique for determining the viability of algal cells by flow cytometry (Gala and Giesy 1994; Caux et al. 1996; Faber et al. 1997; Franklin et al. 2001; Lage et al. 2001; Peperzak and Brussaard 2011) or by fluorescence microscopy (Labra et al. 2007; Nancharaiah et al. 2007). Another approach for the use of FDA consists in the measurement of esterase activity. The intensity of green fluorescence exhibited by live cells depends primarily on the esterase activity of the cell. Using flow cytometry, the reduction of esterase activity on the algal cells, after exposure to different toxicants, was evaluated (Arsenault et al. 1993; Blaise and Menard 1998; Cote et al. 1998; Blaise et al. 2000; Franklin et al. 2001; Regel et al. 2002; Liu et al. 2008; Debenest et al. 2011). In the present work, a low-cost bioassay, performed in a 96-well microplate format, based on the inhibition of the esterases in P. subcapitata, was optimized. FDA is an inexpensive stain and microplate readers are a cost-effective instrumentation alternative to flow cytometers.

P. subcapitata algal cells $\left(5 \times 10^{5}\right.$ cells $\left.\mathrm{ml}^{-1}\right)$ incubated with $20 \mu \mathrm{molL}^{-1}$ FDA for $40 \mathrm{~min}$ allowed a good discrimination between live and metabolically inactive cells. The optimal conditions selected in the present work are intermediary values relative to those found in the literature. As it can be seen in Table 2, the final FDA concentration ranged from 0.024 to $60 \mu \mathrm{molL}^{-1}$. Similarly, a wide range of cell concentrations were used: from $0.1 \times 10^{5}$ to $10 \times 10^{5}$ cells $\mathrm{ml}^{-1}$ (Table 2 ). Regarding the time used for the incubation of the cells with FDA, although a wide time range can also be observed (from 4 to $60 \mathrm{~min}$ ), 10-15 $\mathrm{min}$ was mainly used for flow cytometry (Table 2). Compared to the microplate assay described by Snell et al. (1996), we propose the use of a higher FDA concentration with a lower algal cell concentration. A contact time with the toxicants of 3 or $6 \mathrm{~h}$ was selected, since it corresponds to approximately 25 
Fig. 5 Dose-response plot of cells of $P$. subcapitata exposed to copper. Cells were exposed to different concentrations of $\mathrm{Cu}$ for $3 \mathrm{~h}$ (a) or $6 \mathrm{~h}$ (b) and subsequently incubated with $20 \mu \mathrm{molL}^{-1}$ FDA for 40 min at $25^{\circ} \mathrm{C}$. Cells in the exponential phase of growth (white bars); cells in the stationary phase of growth (grey bars). The percentage of esterase inhibition was calculated considering the maximum fluorescence exhibited by the cells not exposed to heavy metals (control), as described in Section 2. Each point represents the mean of four independent experiments performed in quintuplicate $(n=20)$. The error bars represent the $\mathrm{SD}$ calculated with $95 \%$ confidence limits
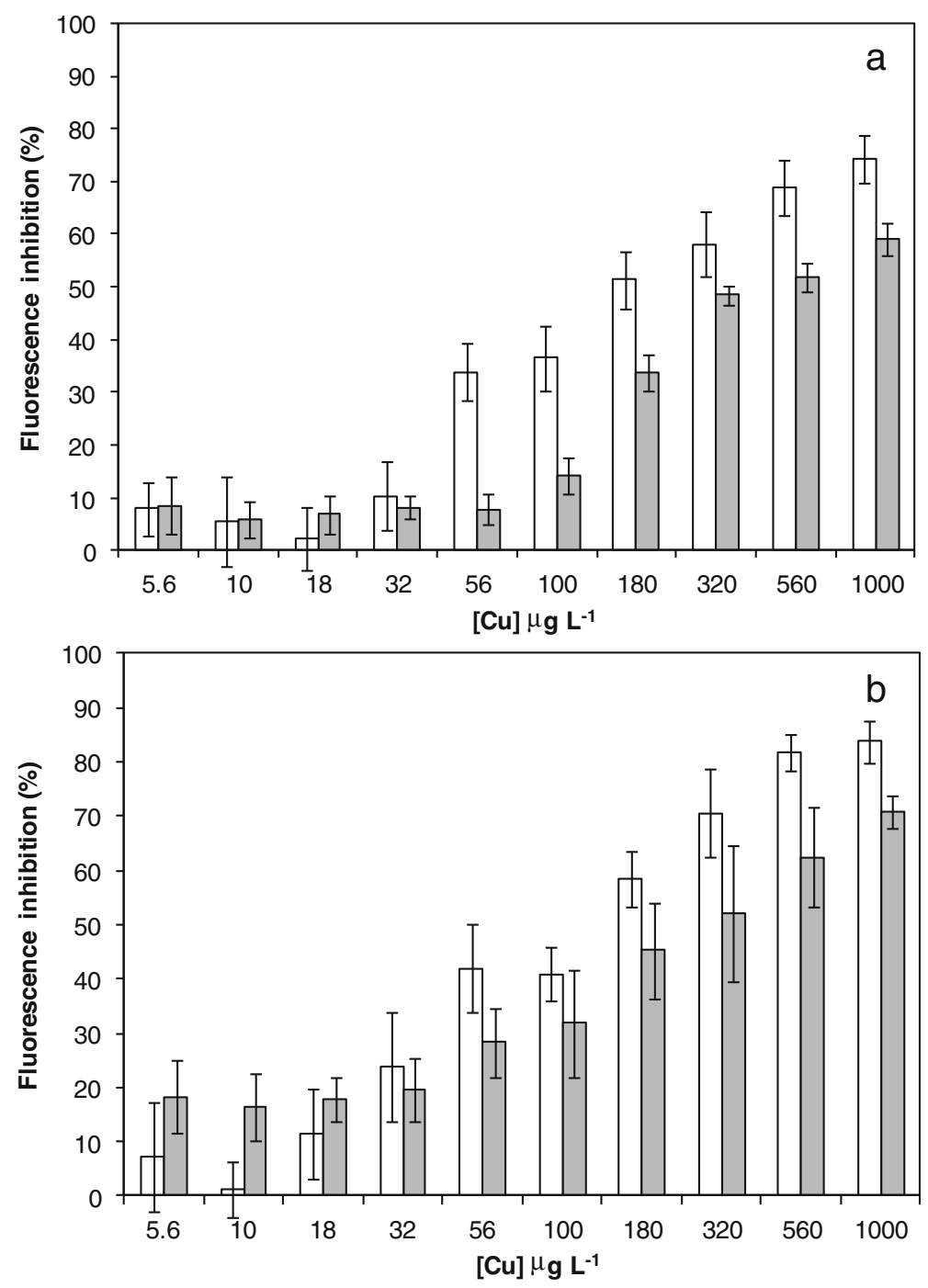

or $50 \%$ of the doubling time of $P$. subcapitata in OECD medium (Fig. 4).
The fluorescence intensity of fluorescein is highly pH-dependent (Haugland 2005). For this reason, the

Table 1 Effect of copper on esterase activity of the algal cells of $P$. subcapitata in the exponential and stationary phases of growth

\begin{tabular}{|c|c|c|c|}
\hline \multirow[t]{2}{*}{ Time of exposure to toxic (h) } & \multirow[t]{2}{*}{ Growth phase } & \multicolumn{2}{|l|}{$\mathrm{EC}\left(\mu \mathrm{gL}^{-1}\right)^{\mathrm{a}}$} \\
\hline & & 10 & 50 \\
\hline \multirow[t]{2}{*}{3} & Exponential & $18(8.0-30)$ & 209 (159-277) \\
\hline & Stationary & $37(0.88-94)$ & $443(229-1,676)$ \\
\hline \multirow[t]{2}{*}{6} & Exponential & $13(6.6-21)$ & $130(102-167)$ \\
\hline & Stationary & $11(3.4-23)$ & $268(185-425)$ \\
\hline
\end{tabular}

$E C$ effect concentration, $E C_{10}$ concentration of copper that induces the inhibition of $10 \%$ of esterase activity on algal cells evaluated using FDA, $E C_{50}$ concentration of copper that induces the inhibition of $50 \%$ of esterase activity on algal cells evaluated using FDA ${ }^{a}$ Values were obtained from four independent experiments performed in quintuplicate $(n=20)$. Values on parenthesis are $95 \%$ confidence limits 
Table 2 Comparison of the staining conditions used for the evaluation of esterase activity, using FDA, on the algal cells

\begin{tabular}{|c|c|c|c|c|c|}
\hline $\begin{array}{l}{[\mathrm{FDA}]} \\
\left(\mu \mathrm{molL}{ }^{-1}\right)\end{array}$ & $\begin{array}{l}\text { Time of incubation } \\
\text { with the dye (min) }\end{array}$ & $\begin{array}{l}\text { Cell concentration } \\
\left(\times 10^{5} \text { cells } \mathrm{ml}^{-1}\right)\end{array}$ & Methodology & Alga & Reference \\
\hline 24 & 60 & NS & MRF & Marine microalgae $^{\mathrm{a}}$ & Gilbert et al. (1992) \\
\hline 60 & $\geq 10$ & 10 & $\mathrm{FC}$ & P. subcapitata ${ }^{\mathrm{b}}$ & Arsenault et al. (1993) \\
\hline 0.024 & 4 & 1 & $\mathrm{FC}$ & P. subcapitata ${ }^{\mathrm{b}}$ & Gala and Giesy (1994) \\
\hline 2.7 & $5-15$ & 7.5 & MRF & Several algae & Snell et al. (1996) \\
\hline 30 & 15 & 10 & $\mathrm{FC}$ & P. subcapitata ${ }^{\mathrm{b}}$ & Blaise and Menard (1998) \\
\hline 24 & 60 & 5 & SP & P. subcapitata & Radix et al. (2000) \\
\hline $1-25$ & $5-10$ & $0.2-0.4$ & $\mathrm{FC}$ & Several algae $^{\mathrm{d}}$ & Franklin et al. (2001) \\
\hline 40 & 9 & 0.2 & $\mathrm{FC}$ & $\begin{array}{l}\text { Microcystis aeruginosa } \\
\text { P. subcapitata }\end{array}$ & Regel et al. (2002) \\
\hline 36 & 10 & NS & $\mathrm{FC}$ & Scenedesmus vacuolatus & Adler et al. (2007) \\
\hline 25 & 8 & 1 & $\mathrm{FC}$ & Chlorella pyrenoidosa & Liu et al. (2008) \\
\hline 0.12 & 15 & 2 & $\mathrm{FC}$ & Chlamydomonas moewusii & Prado et al. (2009) \\
\hline 31 & 15 & $0.1-0.25$ & $\mathrm{FC}$ & Several algae $\mathrm{e}^{\mathrm{e}}$ & Debenest et al. (2011) \\
\hline 10 & 60 & NS & $\mathrm{FC}$ & Phytoplankton strains ${ }^{\mathrm{f}}$ & Peperzak and Brussaard (2011) \\
\hline
\end{tabular}

$F C$ flow cytometer, $M R F$ microplate reader fluorometer, $S P$ spectrofluorometer, $N S$ not specified in the original work

${ }^{\text {a }}$ Tetraselmis suecica, Skeletonema costatum, and Prorocentrum lima

${ }^{\mathrm{b}}$ Formerly known as $S$. capricornutum

${ }^{\mathrm{c}}$ S. capricornutum, T. suecica, Cyclotella sp., and Synechococcus leopoliensis

${ }^{\mathrm{d}}$ S. capricornutum, Chorella sp., Dunaliella tertiolecta, Phaeodactylum tricornutum, Tetraselmis sp., Entomoneis punctulata, and Nitzschia paleacea

${ }^{\mathrm{e}}$ P. subcapitata, Nitzschia palea, and Chlamydomonas reinhardtii

${ }^{\mathrm{f}}$ The work was carried out with 40 phytoplankton strains belonging to cold, warm, and temperate waters

incubation of algal cells with FDA was carried out in a solution buffer at $\mathrm{pH} 7.0$, obtained by the addition of $10 \mathrm{mmolL}^{-1}$ MOPSO; this buffer is appropriate since it does not complex with $\mathrm{Cu}$ (Soares et al. 1999).

In the assay, cells were exposed to the toxicant in growing conditions and the evaluation of the inhibition of esterase activity was carried out in the same microplate without any washing step. Performance of the toxicity assays using the 96-well microplate format has characteristics particularly suitable when we think of the development of methods, which can be used for in situ monitoring in a mobile

Table 3 Comparison of the effect of copper on the esterase activity of the alga P. subcapitata

\begin{tabular}{|c|c|c|c|c|c|c|}
\hline \multirow[t]{2}{*}{ Time of exposure to toxic (h) } & \multirow[t]{2}{*}{ Methodology } & \multirow[t]{2}{*}{ NOEC } & \multirow[t]{2}{*}{ LOEC } & \multicolumn{2}{|c|}{$\mathrm{EC}\left(\mu \mathrm{gL}^{-1}\right)$} & \multirow[t]{2}{*}{ Reference } \\
\hline & & & & 10 & 50 & \\
\hline 1 & Microplate & 200 & 400 & & & Snell et al. (1996) \\
\hline 1 & Flow cytometry & & 40 & & $124(84-185)$ & Franklin et al. (2001) \\
\hline 3 & Flow cytometry & & 40 & & $112(88-143)$ & Franklin et al. (2001) \\
\hline 5 & Spectrofluorometer & 10 & & $11(3-40)$ & $850(230-3,100)$ & Radix et al. (2000) \\
\hline 24 & Flow cytometry & & 10 & & $51(38-70)$ & Franklin et al. (2001) \\
\hline
\end{tabular}

Values in parenthesis are the $95 \%$ confidence limits

$E C$ effect concentration, $E C_{10}$ concentration of copper that induces the inhibition of $10 \%$ of esterase activity on algal cells evaluated using FDA, $E C_{50}$ concentration of copper that induces the inhibition of $50 \%$ of esterase activity on algal cells evaluated using FDA, $N O E C$ no observed effect concentration, $L O E C$ lowest observed effect concentration 
laboratory; other advantages of using this format are: (1) small sample volume; (2) a high number of replicates can be used, which improves the statistical results; and (3) the system can be automated.

Copper was used as reference toxicant since this metal is a frequently found contaminant from urban, industrial, and mining inputs into aquatic systems being considered by the US EPA as a priority pollutant (US EPA 2006). Copper concentration in surface waters vary widely and range from 0.5 to $1,000 \mu \mathrm{g}$ $\mathrm{L}^{-1}$, with average concentrations of $10 \mu \mathrm{gL}^{-1}$. Higher values of copper can be found in polluted areas, such as receiving treated industrial wastewaters or mining drainage. Copper concentrations as high as $69,000 \mu \mathrm{g}$ $\mathrm{L}^{-1}$ were measured in surface waters receiving the drainage from mining operations and abandoned copper mines (ATSDR 2004).

The microplate assay optimized in the present work allowed the evaluation, in a short time (3-6 h), of the effect of the growth phase of the algal cells of $P$. subcapitata on the susceptibility to the action of $\mathrm{Cu}$ (Fig. 5; Table 1). Cells in the exponential phase of growth were two times more sensitive to the action of $\mathrm{Cu}$ than the corresponding cells in the stationary phase (Fig. 5; Table 1). By other words, algal cultures with 2 days (exponential phase) or 4 days (stationary phase) of growth displayed a completely different susceptibility to copper. These results point out the importance of rigorous control of the physiological state of algal cells on ecotoxicity studies. Thus, the evaluation of toxicity using algal cultures with different growth times can be a source of error or inconsistency of the results.

The 3-h $\mathrm{EC}_{10}$ and $\mathrm{EC}_{50}$ values obtained (with algal cells in the exponential phase of growth) are of the same order of magnitude of those described in the literature using flow cytometry (Franklin et al. 2001) (Table 3). Additionally, the $3-\mathrm{h} \mathrm{EC}_{10}$ value obtained is 22 times lower than the value determined as the LOEC (for a 1-h contact time of the algal cells with the toxicant) using a microplate reader (Snell et al. 1996) (Table 3). The 6-h $\mathrm{EC}_{10}$ and $\mathrm{EC}_{50}$ values obtained for $\mathrm{Cu}$, for P. subcapitata algal cells in the exponential phase of growth, are similar or four times lower, respectively, than those described using a spectrofluorometer (5-h $\mathrm{EC}_{10}$ and $\mathrm{EC}_{50}$ values) (Table 3). The 6$\mathrm{h} \mathrm{EC}_{50}$ value obtained is 2.6 times higher than the 24$\mathrm{h}$ EC value described in the literature using flow cytometry (Franklin et al. 2001) (Table 3). However, it is important to point out that the increase of contact time of the algal cells with the toxicants reduces the EC values; thus, it is expected that the $24-\mathrm{h} \mathrm{EC}_{50}$ value should be lower than 6-h $\mathrm{EC}_{50}$ value. In this work, it was our objective to obtain a short-term assay, using a contact time with the toxicant up to half of the duplication time of the algal cells; thus, the 24-h EC values were not determined. The values obtained for the 6$\mathrm{h} \mathrm{EC}_{10}$ and 6-h $\mathrm{EC}_{50}$ values, using algal cells in the exponential phase of growth, were 13 and $130 \mu \mathrm{gL}^{-1}$, respectively, which are within the copper concentrations that can be found in surface waters.

In conclusion, in the present work, a short-term assay, based on the inhibition of esterase activity, was optimized. The esterase inhibition test showed to be a rapid and sensitive endpoint for testing toxicity using the alga $P$. subcapitata. The assay was carried out in a small volume, in 96-well microplates. The algal cells were exposed to the toxicants on growth conditions and all tests were performed in the same microplate, reducing errors due to manipulation (such as loss of cells) and facilitating standardization. The simplicity of manipulation and fluorescence measurement (with the automatic microplate reader) makes this assay particularly well suited for the simultaneous evaluation of short-term algae responses to environmental changes and pollution in large numbers of samples. Additionally, the importance of controlling the physiological state of the algal cells (growth phase) on the susceptibility to copper was demonstrated.

Acknowledgments The authors thank the Fundação para a Ciência e a Tecnologia (FCT) through the Portuguese Government for their financial support of this work through the grant PEST-OE/EQB/LA0023/2011 to IBB. Manuela D. Machado gratefully acknowledges the postdoctoral grant from FCT (SFRH/BPD/72816/2010).

\section{References}

Adler, N. E., Schmitt-Jansen, M., \& Altenburger, R. (2007). Flow cytometry as a tool to study phytotoxic modes of action. Environmental Toxicology and Chemistry, 26, 297306.

Arsenault, G., Cvetkovic, A. D., \& Popovic, R. (1993). Toxic effects of copper on Selenastrum capricornutum measured by a flow cytometer-based method. Water Pollution Research Journal of Canada, 28, 757-765.

ATSDR (2004). Toxicological profile for copper. Atlanta: Agency for Toxic Substances and Disease Registry (ATSDR), 
US Department of Health and Human Services-Public Health Service.

Bitton, G. (2005). Toxicity testing in wastewater treatment plants using microorganisms. Wastewater microbiology (3rd ed., pp. 527-543). Florida: Wiley.

Blaise, C., \& Menard, L. (1998). A micro-algal solid-phase test to assess the toxic potential of freshwater sediments. Water Quality Research Journal of Canada, 33, 133-151.

Blaise, C., \& Vasseur, P. (2005). Algal microplate toxicity test. In C. Blaise, \& J.-F. Férard (Eds.), Small-scale freshwater toxicity investigations (vol. 1, pp. 137-179). Berlin: Springer.

Blaise, C., Gagn, F., \& Bombardier, M. (2000). Recent developments in microbiotesting and early millennium prospects. Water, Air, and Soil Pollution, 123, 11-23.

Caux, P. Y., Menard, L., \& Kent, R. A. (1996). Comparative study of the effects of MCPA, butylate, atrazine, and cyanazine on Selenastrum capricornutum. Environmental Pollution, 92, 219-225.

Cote, C., Blaise, C., Michaud, J. R., Menard, L., Trottier, S., Gagne, F., \& Lifshitz, R. (1998). Comparisons between microscale and whole-sediment assays for freshwater sediment toxicity assessment. Environmental Toxicology and Water Quality, 13, 93-110.

Debenest, T., Petit, A. N., Gagne, F., Kohli, M., Nguyen, N., \& Blaise, C. (2011). Comparative toxicity of a brominated flame retardant (tetrabromobisphenol A) on microalgae with single and multi-species bioassays. Chemosphere, $85,50-55$.

Dorsey, J., Yentsch, C. M., Mayo, S., \& McKenna, C. (1989). Rapid analytical technique for the assessment of cell metabolic activity in marine microalgae. Cytometry, 10, 622628.

Faber, M. J., Smith, L. M. J., Boermans, H. J., Stephenson, G. R., Thompson, D. G., \& Solomon, K. R. (1997). Cryopreservation of fluorescent marker-labeled algae (Selenastrum capricornutum) for toxicity testing using flow cytometry. Environmental Toxicology and Chemistry, 16, 1059-1067.

Franklin, N. M., Adams, M. S., Stauber, J. L., \& Lim, R. P. (2001). Development of an improved rapid enzyme inhibition bioassay with marine and freshwater microalgae using flow cytometry. Archives of Environmental Contamination and Toxicology, 40, 469-480.

Franklin, N. M., Stauber, J. L., \& Adams, M. S. (2005). Improved methods of conducting microalgal bioassays using flow cytometry. In G. K. Ostrander (Ed.), Techniques in aquatic toxicology (Vol. 2, pp. 735-756). Boca Raton: CRC.

Gala, W. R., \& Giesy, J. P. (1994). Flow cytometric determination of the photoinduced toxicity of anthracene to the green alga Selenastrum capricornutum. Environmental Toxicology and Chemistry, 13, 831-840.

Gilbert, F., Galgani, F., \& Cadiou, Y. (1992). Rapid assessment of metabolic activity in marine microalgae: Application in ecotoxicological tests and evaluation of water quality. $\mathrm{Ma}$ rine Biology, 112, 199-205.

Haugland, R. P. (2005). pH indicators. In M. T. Z. Spence (Ed.), The handbook-A guide to fluorescent probes and labeling technologies (pp. 935-955). Carlsbad: Invitrogen Corporation.
Jochem, F. J. (2000). Probing the physiological state of phytoplankton at the single-cell level. Scientia Marina, 64, 183195.

Labra, M., Bernasconi, M., Grassi, F., De Mattia, F., Sgorbati, S., Airoldi, R., \& Citterio, S. (2007). Toxic and genotoxic effects of potassium dichromate in Pseudokirchneriella subcapitata detected by microscopy and AFLP marker analysis. Aquatic Botany, 86, 229-235.

Lage, O. M., Sansonetty, F., O’Connor, J. E., \& Parente, A. M. (2001). Flow cytometric analysis of chronic and acute toxicity of copper(II) on the marine dinoflagellate Amphidinium carterae. Cytometry, 44, 226-235.

Liu, H. L., Yu, Y., Kong, F. X., He, L. N., Yu, H. X., Giesy, J. P., \& Wang, X. R. (2008). Effects of tetrabromobisphenol A on the green alga Chlorella pyrenoidosa. Journal of Environmental Science and Health Part a-Toxic/Hazardous Substances \& Environmental Engineering, 43, 1271-1278.

Nancharaiah, Y. V., Rajadurai, M., \& Venugopalan, V. P. (2007). Single cell level microalgal ecotoxicity assessment by confocal microscopy and digital image analysis. Environmental Science and Technology, 41, 2617-2621.

OECD (1984). Alga, growth inhibition test (201). OECD guideline for testing of chemicals. Paris: Organization for Economic Co-operation and Development.

OECD (1992). Fish, acute toxicity test (203). OECD guideline for testing of chemicals. Paris: Organization for Economic Co-operation and Development.

Peperzak, L., \& Brussaard, C. P. D. (2011). Flow cytometric applicability of fluorescent vitality probes on phytoplankton. Journal of Phycology, 47, 692-702.

Prado, R., Garcia, R., Rioboo, C., Herrero, C., Abalde, J., \& Cid, A. (2009). Comparison of the sensitivity of different toxicity test endpoints in a microalga exposed to the herbicide paraquat. Environment International, 35, 240-247.

Radix, P., Leonard, M., Papantoniou, C., Roman, G., Saouter, E., Gallotti-Schmitt, S., Thiebaud, H., \& Vasseur, P. (2000). Comparison of four chronic toxicity tests using algae, bacteria, and invertebrates assessed with sixteen chemicals. Ecotoxicology and Environmental Safety, 47, 186-194.

Regel, R. H., Ferris, J. M., Ganf, G. G., \& Brookes, J. D. (2002). Algal esterase activity as a biomeasure of environmental degradation in a freshwater creek. Aquatic Toxicology, 59, 209-223.

Snell, T. W., Mitchell, J. L., \& Burbank, S. E. (1996). Rapid toxicity assessment with microalga using in vivo esterase inhibition. In G. K. Ostrander (Ed.), Techniques in aquatic toxicology testing (pp. 13-22). Boca Raton: CRC.

Soares, H., Pinho, S. C., \& Barros, M. (1999). Influence of $n$ substituted aminosulfonic acids with a morpholinic ring $\mathrm{pH}$ buffers on the redox processes of copper or zinc ions: A contribution to speciation studies. Electroanalysis, 11, 1312-1317.

Soares, E. V., Duarte, A. P. S. R., Boaventura, R. A., \& Soares, H. M. V. M. (2002). Viability and release of complexing compounds during accumulation of heavy metals by a brewer's yeast. Applied Microbiology and Biotechnology, 58, 836-841.

Soares, E. V., Hebbelinck, K., \& Soares, H. M. V. M. (2003). Toxic effects caused by heavy metals in the yeast 
Saccharomyces cerevisiae: A comparative study. Canadian Journal of Microbiology, 49, 336-343.

US EPA (2002a). Methods for measuring the acute toxicity of effluents and receiving waters to freshwater and marine organisms (5th ed., pp. 1-266). EPA-821-R02-012. Washington, DC: Environmental Protection Agency.
US EPA (2002b). Short-term methods for estimating the chronic toxicity of effluents and receiving waters to freshwater organisms (4th ed., pp. 1-350). EPA-821-R-02-013. Washington, DC: Environmental Protection Agency.

US EPA (2006). National recommended water quality criteria. Washington, DC: United States Environmental Protection Agency Office of Water, Science and Technology (4304T). 